\title{
LUGARES DISTINTOS, REALIDADES SEMELHANTES: NOTAS SOBRE O PROCESSO DE TRANSFORMAÇÃO DO PANORAMA RELIGIOSO NO BRASIL E NA ARGENTINA
}

\author{
Marcelo Tadvald
}

Resumo: Ao longo do século XX, Brasil e Argentina fomentam na relação de suas sociedades com o Estado e com o campo religioso disponível o cenário e as condiçóes sociais e políticas que ajudam a compreender o complexo fenômeno da transnacionalização religiosa entre ambos os países. A partir de uma análise histórica e antropológica, procuro mapear e interpretar de forma sensível ao novo contexto globalizado a entrada de elementos do mundo religioso brasileiro na Argentina, com foco na migração da Igreja Universal do Reino de Deus.

Palavras-chave: Religião e política; Argentina; Brasil; fluxo religioso.

Abstract: Along the $20^{\text {th }}$ Century, Brazil and Argentina promote in the relation of its societies with the State and the available religious filed the scenery and the social and political conditions that help to understand the complex religious trans-nationalization phenomenon's between both countries. From a historical and anthropological analysis, I try to interpret in a sensitive way, under the new globalized context, the entry of the brazilian religious world elements in Argentina, focusing the migration of the Universal Church of the Kingdom of God.

Keywords: Religion and politics; Argentina; Brazil; religious flow.

Quem controla o passado controla o futuro. Quem controla o presente controla o passado.

George Orwell

${ }^{1}$ Doutorando do Programa de Pós-Graduação em Antropologia, UnB. Pesquisador do Núcleo de Estudos da Religião (NER-PPGAS-UFRGS).

Debates do NER, Porto Alegre, Ano io, N. I6, P. I39-I59, JUl./DeZ. 2009 


\section{RELIGIOSIDADES DE EXPORTAÇÃO}

O fluxo religioso entre o Brasil e a Argentina se realiza a partir de diferentes formas de religiosidade. Esta análise se volta para o caso das religióes evangélicas brasileiras exportadas para o país platino, em particular a Igreja Universal do Reino de Deus (doravante IURD). As razóes desta escolha serão mais bem mostradas ao longo da discussão. Adianto que algumas religióes evangélicas possuem projetos expansionistas institucionalizados e sua entrada em diversos países é vista como um importante fenômeno que chamou a atenção de alguns pesquisadores, especialmente desde as duas últimas décadas, de sorte que a IURD se encontra em um patamar privilegiado dentro deste contexto. Sua exportação do Brasil para inúmeros países do mundo, especialmente para locais aonde as instituiçōes democráticas se encontram em processos de afirmação, devido a regimes ditatoriais recentemente destituídos (como é o caso da maioria dos países latino-americanos ao longo dos anos 1980) ou aos também recentes processos de independência (como é o caso de muitos dos países africanos, ao longo dos anos 1970-80) revelou que sua capacidade de adaptação varia conforme os contextos sociais receptores (Oro, 2003). Por outro lado, a escolha em analisar a Argentina ocorreu, sobretudo, pela sua conexão histórica com o Brasil já constatada pelas etnografias pré-existentes de fluxos religiosos entre os dois países.

É preciso analisar o fenômeno a partir de sua manifestaçáo em três diferentes instâncias, que formam a tríade religião, sociedade, Estado. As três instâncias, no cenário que se apresenta, encontram-se em permanente diálogo, todas provocando sensíveis transformaçōes e conformaçoos entre si. A complexidade do processo inviabiliza seu maior desdobramento neste texto, mas é importante observar sua relevância enquanto estrutura interativa, por sua vez elementar na configuração do fenômeno da transnacionalização.

A imbricação do campo religioso no campo político se configura em um importante fenômeno que também despertou o interesse de diversas pesquisas ao longo dos últimos anos. De forma particular, certas expressões religiosas evangélicas, como a IURD, possuem um projeto político de inserção neste campo, e acho possível antecipar que esse projeto, com

Debates do NER, Porto Alegre, ANo io, N. 16, P. I39-I59, JUl./DeZ. 2009 
maior ou menor sucesso, mediante uma série de fatores correlatos procura também ser exportado para os países em que a IURD se faz presente, como no caso da Argentina. O problema é que ao adentrarem em outros países, essas religióes encontram contextos sociais, culturais e políticos particulares e não necessariamente sua entrada - e, com ela, a aplicaçáo de seu projeto político, realiza-se de forma plenamente satisfatória. Isso implicará na adoção de estratégias institucionais que busquem o caminho adequado ao novo cenário para alcançar esses objetivos.

Parto de uma breve análise dos distintos contextos nacionais utilizando como filigrana analítica certos processos históricos e sociais de imbricação entre a esfera religiosa e a esfera política, a fim de contextualizar os cenários e as condiçóes que permitiram o trânsito de religiosidades entre os países, em especial aquela agenciada pela IURD.

\section{NOTAS HISTÓRICAS SOBRE A INSERÇÃO RELIGIOSA NO CAMPO POLÍTICO BRASILEIRO E NO CAMPO POLÍTICO ARGENTINO}

Ao se falar sobre a imbricação do campo religioso no campo político é necessário levarmos em conta o fenômeno da secularização ${ }^{2}$. Talvez o pro-

${ }^{2}$ Em linhas gerais, secularização remete a um conjunto de mudanças na forma pela qual o religioso é percebido pela sociedade, ocorridas ao longo do último século, que colocaram em xeque sua privilegiada posição de instância organizadora das sociedades. Cada qual a sua maneira, os clássicos das Ciências Sociais atuais apostaram no chamado "desencantamento do mundo" para explicar a perda de hegemonia do religioso dentro da sociedade moderna, agora industrializada, urbana, complexa e orientada pela racionalidade. Max Weber foi, contudo, quem mais se destacou dentre aqueles pensadores que apostaram neste "desencantamento do mundo" (Weber, 2004). A secularização em si, advinda deste fenômeno maior de "desencantamento", consistiria em um processo mais recente, que implicaria em um abandono do religioso até o nível em que sua influência no social fosse cada vez menor. Instâncias como a Economia e a Política se orientariam a partir de estímulos meramente "racionais", "técnicos" e "lógicos", sobrando menos espaço para as influências advindas do campo religioso, outrora basilares para os desígnios destas e de outras dimensóes do social.

Debates do NER, Porto Alegre, ano io, N. I6, P. I39-I59, JUl./Dez. 2009 
cesso mais importante resultante deste fenômeno seja a maior fragmentação do religioso no meio social, que permite a existência de maior capacidade de escolha religiosa por parte dos indivíduos. O fenômeno de secularização (especialmente no que se refere ao campo político, na separação do Estado da religião) não ocorreu de forma uniforme nos diferentes países ocidentais, mesmo que a perda da hegemonia de certas expressóes religiosas no que diz respeito à orientação do Estado e da sociedade em geral seja perceptível na maioria deles. Tanto o Brasil quanto a Argentina apresentam processos diferentes com relação ao assunto, mas em ambos os países o religioso ainda se mantém como uma importante e estratégica instância, tanto do ponto de vista social, quanto do ponto de vista político.

No caso brasileiro, tem-se uma clara noção relativa aos seus movimentos históricos de secularização desde a sua primeira Constituição da Era Republicana. Anteriormente, durante o período colonial e imperial, prevaleceu o vínculo legal entre o Estado e a Igreja Católica. Desde a Constituição de 1891, a separação entre a Igreja e o Estado já se tornara lei, além da instituição da liberdade religiosa para todos os indivíduos e credos ${ }^{3}$.

No caso argentino, ao longo do século XIX o país alinhou-se aos interesses da Grã-Bretanha, o que lhe permitiu um dos maiores desenvolvimentos econômicos da América Latina durante o período que se estendeu de forma relativamente satisfatória até o advento da Segunda Guerra Mundial. Devido a essa prosperidade, o país atraiu um número considerável de imigrantes. Para se ter uma idéia, em 1895, dois em cada três habitantes da capital Buenos Aires era estrangeiros, especialmente europeus provenientes da

${ }^{3}$ Desde o advento da República, proclamada em 1889, o novo governo inspirado na forma republicana francesa, manifestou seu ideário de separação entre o Estado e a Igreja, o que revelou uma redefinição do campo religioso brasileiro, ocorrida ao longo do século XX. Sancionado pelo Governo Provisório, o Decreto n. 119A de sete de janeiro de 1890, de autoria de Rui Barbosa, separou a Igreja Católica do Estado, extinguiu o padroado, proibiu os órgãos e autoridades públicas de expedir leis, regulamentos ou atos administrativos que estabelecessem religião ou a vedassem e instituiu plena liberdade de culto e de religião para os indivíduos e todas as confissóes, igrejas e agremiaçóes religiosas (Giumbelli, 2002).

Debates do NER, Porto Alegre, ANo io, N. 16, P. I39-I59, JUl./DeZ. 2009 
Itália e em menor número, da Espanha e da França (Romero, 2006). Até a década de 1920, a proporção demográfica de estrangeiros se mantinha impressionante, dado que quase metade da população era composta por imigrantes. À exceção de alguns grupos, como os de inspiração anarquista, a maioria dos imigrantes europeus trazia consigo a instrução religiosa católica de seus países de origem (por certo, notoriamente católicos) e reforçaram a importância desta religião no país de destino, que ao longo do século XIX havia se tornado dominante dentro do discurso oficial do Estado.

Ao longo do século XIX, da mesma maneira que o Brasil e outros vizinhos americanos, o Estado argentino via na imigração de populaçóes de "europeus brancos" o grande instrumento do progresso. Até meados do século XX, o perfil da sociedade argentina era dominado por imigrantes ou pela primeira geração de seus filhos. Esta peculiaridade deu origem a um contingente populacional que não possuía fortes laços com o lugar, uma vez que desejavam prosperar no país o suficiente para voltar para sua terra natal ou de seus antepassados recentes. Nas primeiras décadas do século XX, o Estado já se mostrava preocupado com esse panorama. Sua associaçáo com a Igreja Católica foi, nesse momento, crucial para aplicar determinados projetos que visassem a plena integração populacional e a criação de uma "identidade nacional argentina”. A educação primária pública foi escolhida como o "grande projeto de integração" (Lobato, 2000). Ainda que ela existisse desde os anos 1880 e já sob a tutela da Igreja Católica (grande parte das escolas públicas eram gerenciadas pela Igreja, sendo seu corpo funcional formado por agentes religiosos), o ensino religioso obrigatório na formação dos alunos consistia em uma das estratégias para a criação do "sentimento de pertencimento pátrio". Associada ao Estado, a Igreja contribuiu decisivamente para, nas palavras do historiador Luis Alberto Romero (2006, p. 27): "argentinizar a massa estrangeira", de preferência através de uma orientação religiosa católica.

O projeto de construção de uma identidade nacional brasileira, antes dispersa e com pouco alcance no território nacional, recebeu novo impulso com a Revolução de 1930. Com o advento da Era Vargas, tal projeto recebeu abrangência nunca vista na história do país. Apesar da separação

Debates do NER, Porto Alegre, ano io, N. I6, P. I39-I59, JUl./DeZ. 2009 
constitucional entre Igreja e Estado, o catolicismo também foi utilizado no Brasil pelo governo de Getúlio Vargas como elemento de identificação religiosa das massas. A Igreja católica teve uma associação com o governo importante neste período. De maneira similar ao caso argentino, a Igreja Católica conseguiu garantir constitucionalmente no Brasil o ensino religioso facultativo nas escolas públicas. Contudo, neste contexto e no decorrer do século XX se verificou no Brasil o surgimento e/ ou crescimento substancial de formas de religiosidades que iam de encontro ao ideal católico de monopólio religioso. Na Argentina, por outro lado, sempre foi importante a presença de diversas ordens, movimentos sociais e intelectuais e mesmo instituiçōes de discurso anticatólico que podem ser agrupados sob a égide do pensamento positivista argentino (Soler, 1968).

Domingo Faustino Sarmiento, que presidiria a Argentina entre 1868-1874, de certa maneira centralizou na sua figura o posicionamento anticatólico argentino de sua época, que se faria presente ao longo de todo o século XX e que forçou, em diversos momentos históricos, a associação da Igreja com certos governos (na maioria das vezes, de caráter ditatorial) a fim de combater certas religiōes, instituiçōes ou movimentos sociais e políticos que colocassem em risco o espaço de poder tanto da própria Igreja quanto dos grupos sociais que sustentavam o poder. A título de exemplo, a partir dos anos 1920, o país começou a sofrer com a crise econômica internacional advinda dos efeitos da Primeira Guerra Mundial. No auge da crise, em 1919, a Igreja organizou todas as instituições católicas que atuavam na sociedade dentro de um movimento mundial que no país platino recebeu o nome de União Popular Católica Argentina, que consistia em um exército laico comandado pela cúpula da Igreja que se propunha a enfrentar, junto com o Estado, movimentos socialistas, anarquistas ou afins, além de criar bibliotecas, dispensários, conferências e obras assistencialistas e de caridade, empreendimentos que recrutavam pessoas dos altos círculos sociais que deveriam adquirir, com isso, a consciência de sua elevada missão redentora. Não obstante, a Igreja, cada vez mais resistente às instituiçôes democráticas, encerrava a possibilidade de criar um partido político, algo que era bem cogitado na época (Romero, 2006).

Debates do NER, Porto Alegre, ANo io, N. 16, P. I39-159, JUl./Dez. 2009 
No Brasil, a associação da Igreja católica com o Estado se realizou de forma mais indireta, mesmo porque o Estado argentino conseguiu efetivar um projeto de centralização cultural com maior sucesso do que no Brasil à época, se levarmos em conta os projetos dos governos em ambos os países até, especialmente, o final da Segunda Guerra Mundial. É interessante considerar também que a forte cultura autoritária peculiar do meio militar argentino (corrobora este aspecto o fato do país platino ter tido, ao longo do século XX, mais períodos sob ditaduras militares do que democráticos) possuir uma forte semelhança com a cultura autoritária presente no militarismo do Rio Grande do Sul. As aproximaçóes culturais entre os gaúchos brasileiros com a cultura gaucha rio-platense se estende para diversas dimensóes. Ainda que não seja o momento pertinente para desenvolver certas aproximaçôes macro-culturais, parece importante observar que tanto Getúlio Vargas quanto quatro dos cinco presidentes militares da ditadura brasileira pós-golpe de 1964 tiveram sua formação militar no extremo sul do país. A intenção de compreender em que medida os diferentes Estados podem ter contribuído para o fluxo de religióes e de que maneira as sociedades nacionais e seus diferentes grupos se envolveram nesse processo deve levar em consideração certas contingências históricas, especialmente quando é possível encontrar semelhanças estruturais na política dos dois países em momentos específicos.

Por exemplo, nos anos 1930, algumas lideranças católicas brasileiras se esforçaram para criar a Liga Eleitoral Católica (LEC), a fim de incentivar a eleição para a Assembléia Nacional Constituinte de políticos que defendessem seus interesses na Constituição que viria a ser promulgada em 1934. Esta Carta foi suspensa após o golpe de Estado promovido pelo grupo liderado por Getúlio Vargas. No caso da participação de religiosos no campo político, esta se tornou novamente possível a partir de 1945, com a instauração de uma nova constituinte após o término do Estado Novo, ainda que, na Constituição de 1934 tenha se introduzido o princípio da "colaboração recíproca” entre Estado e religião. Evidentemente, religiāo nesse contexto se referia à Igreja Católica. A Constituição de 1946 reafirmou este princípio, que somente seria contestado pela Constituição de 1967, que interpôs

Debates do NER, Porto Alegre, Ano io, N. I6, P. I39-I59, JUl./DeZ. 2009 
uma cláusula restritiva à "colaboração recíproca", em consonância com o paradigma político da junta militar que comandava o país. A Constituição de 1988 manteve os dispositivos vigentes nas Constituiçôes anteriores que separavam a Igreja do Estado, afirmando o Brasil como um país político e juridicamente laico (Giumbelli, 2002).

De maneira semelhante ao Brasil - e com clara inspiração nas práticas do Estado fascista italiano que objetivava harmonizar capital e trabalho, a partir dos anos 1930 a Argentina desenvolveu o seu processo de industrialização devido ao interesse do capital estrangeiro na abertura de novos mercados na América Latina. Os interesses políticos de alguns grupos econômicos estrangeiros alocados na Argentina, além de outros nacionais, forçaram a reabertura política, que culminou nas eleições presidenciais de 1937. Entretanto, o "clima democrático" sucumbiria perante a eclosão da Segunda Guerra Mundial. Em 1943, novamente os militares assumiram o poder graças a um golpe de Estado. Nesta época surgiu a figura do então coronel Juan Domingo Perón, que iria marcar decisivamente a história política argentina até os dias atuais.

O militar venceu as eleições de 1946. O primeiro governo peronista manteve o ensino religioso nas escolas (conforme determinação do governo militar que o precedera), além de conceder a direção das universidades a figuras relacionadas com o clericalismo, isto porque existia na época espécie de acordo básico do Estado platino com a Igreja, já que esta apoiou veladamente a candidatura de Perón, o que significa dizer, em outras palavras, que a Igreja não se opôs publicamente a eminente vitória nas urnas do então coronel, em 1946. Além disso, o governo incorporou na sua lista de colaboradores destacados sacerdotes da Igreja, inclusive o padre Virgílio Filippo, pároco do bairro de Belgrano, eleito para o Congresso Nacional no mesmo pleito que elegeu Perón, prática até então pouco comum, senão inédita.

Ainda assim, a relação entre o governo Perón e a Igreja foi de um relativo distanciamento, o que incomodou algumas lideranças clericais que viam neste governo a ascensão de um autoritarismo preocupante. Nas eleiçóes de 1951, a primeira que permitiu o voto das mulheres, em parte devido à destacada figura de "Evita" Perón, a primeira-dama mais marcante da história 
do país, Juan Domingo Perón foi reeleito. Neste segundo mandato, o regime teve uma tendência clara de "peronizar" todas as instituiçóes, transformandoas em instrumentos de doutrinamento ideológico, prática de inspiração fascista largamente utilizada durante o Estado Novo no Brasil. Deixando a Igreja à parte desse projeto, a reação veio antes mesmo do término do segundo mandato, pois "a fundação do Partido Democrata Cristão marcou o começo do conflito entre Perón e a Igreja, o que rapidamente levou à sua queda" (Romero, 2006, p. 122).

O conflito entre as duas instituiçôes eclodiu em setembro de 1954, nas celebraçôes do Dia do Estudante. A partir de então, o governo procurou expor os "tremendos vícios da Igreja": as procissōes foram proibidas, suprimiu-se o ensino religioso obrigatório nas escolas e - de forma incrível para a época - introduziu-se a uma lei sobre outra questão uma cláusula que deveria permitir o divórcio. Além disso, foi autorizada reabertura dos prostíbulos e se tentou pela primeira vez realizar uma reforma constitucional que separasse a Igreja do Estado. Esta última iniciativa não obteve sucesso. Contudo, na época, diversos sacerdotes foram presos e os jornais (devidamente coordenados pelo Estado) se encheram de conteúdos anticlericais.

Os governos (militares ou civis) que sucederam a primeira fase do peronismo até o final dos anos 1960 foram marcados por uma reaproximaçáa com a Igreja Católica, graças ao seu desalinhamento com certos princípios da Era Perón. Digna de registro, uma medida que reaproximou as duas instituiçóes historicamente cúmplices na administração do poder argentino foi, por parte do então primeiro Ministro da Educação pós-regime Perón (um católico tradicionalista), a autorização do funcionamento de universidades particulares, conforme pleiteava há algum tempo a Igreja.

Esta associação entre a Igreja católica e o Estado argentino de natureza centralizadora indica, ao longo do período mencionado, uma sutil relaçáo de dependência de interesses. Enquanto os ditames do Estado serviam aos interesses da religião católica, este teve o seu apoio, e vice-versa, como em 1966, quando a Igreja apoiou o governo militar que recentemente assumira o poder. Na ocasião, a associação da Igreja com o Estado se mostrou evidente quando a censura do governo se estendeu às manifestaçóes mais diferentes

Debates do NER, Porto Alegre, ano io, N. I6, P. I39-I59, JUl./Dez. 2009 
dos novos costumes da época, como as minissaias e o cabelo comprido, percebidas pela Igreja como uma "porta aberta" ao comunismo, assim como o "amor livre", a pornografia e o divórcio. Associando-se ao Estado, a Igreja conseguiu o apoio de muitos grupos, inclusive de parte dos intelectuais e acadêmicos, que viam também nos efeitos da modernidade perigos que deveriam ser combatidos com a autoridade do Estado (Romero, 2006).

A associação da Igreja católica com o Regime Militar brasileiro (19641985) não teve a mesma importância se comparado ao que ocorreu na Argentina. Neste país, após um breve período democrático, a junta militar presidida pelo General Videla assumiu o poder em março de 1976 e o regime perduraria até 1983. Enquanto serviu aos seus interesses, a Igreja apoiou o regime de forma substancial, apoio que foi recrudescendo à medida que o regime militar começou a dar sinais de fraqueza. Complacentes na maior parte do tempo, não foram poucos os mais influentes sacerdotes da Igreja que prosperaram com o governo militar, seja de forma a conquistarem mais poder, seja de forma explicitamente econômica. Não obstante, a Igreja corroborava as declaraçóes do Governo que aludiam ao terrorismo de Estado e à virtude cristá, calando todas as críticas e tolerando que diversos de seus membros ajudassem o esforço militar a "erradicar todas as ameaças".

Porém, havia reciprocidade enquanto a relação entre o Governo e a Igreja foi amistosa. Prova disso foi a criação pelos militares do Registro Nacional de Cultos, em 1978, que tinha o propósito de resolver questóes relativas às instituiçôes religiosas existentes no país diferentes da Igreja Católica. No Brasil ocorreu algo semelhante e, à exemplo do que ocorre na Argentina, o Registro Brasileiro de Cultos ainda existe, contrariando em tese o princípio legal de "liberdade religiosa" consagrado na Constituição Nacional. Em ambos os países o Estado criou uma instituição para tutelar e gerenciar a diversidade religiosa, conforme os princípios e interesses da Igreja, ainda que no Brasil tal instituição tenha peso e alcance menor se comparado ao exemplo argentino. Dentre outras coisas, no caso argentino, o Registro Nacional de Cultos prevê até hoje a inscrição obrigatória dos diversos grupos religiosos para que esses possam funcionar no país (Catoggio, 2007). No Brasil, tais arbitrariedades são mais porosas. Contudo, conforme tive oportunidade de

Debates do NER, Porto Alegre, Ano io, N. 16, P. I39-I59, JUl./DeZ. 2009 
constatar em Buenos Aires, desde o primeiro governo Kirscher, o organismo estatal possui caráter menos regulador e um discurso mais voltado para a pluralidade religiosa.

Coincidência ou não, a Igreja católica da Argentina começa a mudar sua postura por volta de 1979, quando o genocídio promovido pelos militares conseguira "erradicar" boa parte das "ameaças ao Estado". Em 1981, a Igreja, provavelmente temendo sucumbir junto com os militares, tamanha era a consternação nacional em torno do pouco que à época se sabia a respeito das atrocidades cometidas pela Junta Militar que presidia o país, lançou o documento Igreja e comunidade nacional, em que afirmava os princípios republicanos, indicando a clara opção da Igreja pela democracia e seu afastamento do regime militar, se somando, portanto, aos crescentes protestos da sociedade civil pelo fim do regime.

Este e outros exemplos de associação da cúpula católica com o Estado na Argentina indicam a necessidade histórica dessa religião em combater algum "inimigo iminente", fosse ele algum movimento social, religioso ou político. O Estado centralizador também teve esse tipo de interesse em alguns momentos históricos e quando o "inimigo" era comum, supóe-se que a associação se mostrou absolutamente pertinente. Ao contrário do Brasil, as elites argentinas que alternaram o poder político do Estado nunca possuíram a coesão que as elites brasileiras mostraram possuir depois da primeira Era Vargas (1930-1945), que inclusive teve aí um de seus principais projetos políticos bem-sucedidos. Se por um lado existiu e de forma renovada permanece na Argentina o ethos patronal e ruralista absolutamente católico e conservador, que repercute na tradição militar rio-platense, incluindo aí o extremo sul do Brasil, por outro também apareceram ao longo da história correntes absolutamente anticlericais de inspiração positivista, anarquista, ateísta, agnóstica, assim por diante (Soler, 1968). Quer dizer, muitos grupos sociais tiveram que travar lutas históricas contra o regime do patronato católico, estivesse ele presente tanto na cúpula do Governo quanto nas localidades mais remotas do país.

Em minha recente pesquisa na Argentina, observei que o catolicismo ainda se constitui como a principal força religiosa do país. Contudo, tam-

Debates do NER, Porto Alegre, ano io, N. I6, P. I39-I59, JUl./Dez. 2009 
bém observei forte movimento anticatólico presente na cidade de Buenos Aires. O espaço urbano é tomado por ambos os discursos, não sendo preciso haver uma grande passeata ou procissão para se notar isso. Ofereço dois exemplos observados em minhas despretensiosas caminhadas pela capital daquele país.

Passando pela Praça de Maio (a mais importante da capital, onde se encontra a sede do Poder Executivo, por exemplo) visitei a Catedral da cidade, o principal templo católico do país que também se encontra nas imediaçóes da praça. Chamou minha atenção algumas intervenções gráficas de tamanho considerável presentes na entrada da Catedral, com dizeres ofensivos ou críticos à Igreja católica, tais como: "Iglesia Genocida", "Iglesia asesina", etc. Depois deste evento, percebi ao percorrer a cidade a existência de inúmeras intervençóes espalhadas em muros de prédios públicos, de construções do entorno da Plaza de Mayo, nas calçadas sobre a faixa de pedestres, entre outras também observadas em regióes mais afastadas do centro, com dizeres anticatólicos, sendo as paredes das igrejas o local preferido deste tipo de manifestação. O último que vi, grafitado na coluna do templo e relativo naturalmente à posiçáo católica perante o aborto, dizia algo do tipo, em tradução livre: "não enrolem seus rosários em nossos ovários". Por outro lado, ao voltar para casa num bonito entardecer de domingo, casualmente passei em frente a Iglesia de San Nicolas, localizada em uma região nobre da Avenida Santa Fé, próxima ao centro. Por ser horário de missa, a igreja estava tão cheia que, por falta de espaço, as últimas pessoas comungavam se ajoelhando nas escadarias da parte externa do templo. O que mais chamou a atenção no evento, contudo, foi a quantidade de adolescentes e de jovens adultos de classe média participando do evento, algo absolutamente inusitado no Brasil, em tais circunstâncias e contexto aproximados.

Ao procurar imbricaçóes entre o campo religioso e o campo político na Argentina, centralizei propositalmente a análise no caso da Igreja católica. Contudo, é importante mencionar que o país possui relativa pluralidade religiosa, ainda que, dentro do discurso oficial sua nação seja eminentemente católica. Ademais, a necessidade de associação deste campo religioso com o Estado ao longo de todo o século XX (e mesmo em boa parte do XIX)

Debates do NER, Porto Alegre, ANo io, N. 16, P. I39-I59, JUl./DeZ. 2009 
revela justamente a existência de tal pluralidade religiosa. No caso brasileiro, a sociedade e o Estado tiveram uma relação historicamente diferente em diversos aspectos, em parte devido à falta de capacidade centralizadora deste, talvez devido à extensão de seu território e do menor alcance do Estado em localidades muito distantes, o que náo impediu que no Brasil a pluralidade social e religiosa encontrasse terreno mais fértil para se reproduzir, mesmo tendo de lidar com as investidas repressivas do Estado, menos eficientes se comparado ao exemplo do país vizinho.

Dentro deste princípio estrutural da diferença que não soçobrou inteiramente ao Estado, ao contrário, foi amplamente utilizado por ele em seus variados projetos de integração nacional, o Brasil se notabilizou pelo fomento de expressóes religiosas que encontraram espaço em contextos transnacionais, como o argentino. No que se refere exclusivamente ao campo político, com o final do período ditatorial, em 1985, a onda de redemocratização que tomou o país abriu espaço para que certas religióes se inserissem de forma mais contundente na arena política, e os evangélicos tomaram a frente neste processo. Na Argentina, apesar de terem encontrado campo fértil para o seu desenvolvimento, tais expressóes religiosas brasileiras encontram muitas dificuldades para adentrarem na arena política daquele país.

\section{NOTAS SOBRE A IGREJA UNIVERSAL NO CENÁRIO SOCIO-POLÍTICO BRASILEIRO E ARGENTINO}

Desde a sua formação, por volta dos anos 1980, a "bancada evangélica brasileira" tem se notabilizado por seus posicionamentos referentes a temas polêmicos, como a liberdade sexual, o aborto, a eutanásia, a união civil entre pessoas do mesmo sexo, direitos das mulheres, assim por diante, sempre advogando uma pretensa "maioria moral" que prima pelo conservadorismo a respeito destas questóes, a exemplo do discurso tradicional católico sobre os mesmo temas (Machado, 2006).

A inserção evangélica no campo político brasileiro revelou o relativo sucesso da Assembléia de Deus e da IURD nas eleições após a reabertura

Debates do NER, Porto Alegre, ano io, N. I6, P. I39-I59, JUl./Dez. 2009 
política. Entretanto, foi a IURD quem mais chamou a atenção da opinião pública e de diversos pesquisadores, devido ao seu projeto político institucionalizado e a sua agressiva política de expansão, a partir de um aparato considerável de meios de comunicação que servem para veicular sua doutrina evangelista para todo o mundo em que se faz presente.

A pesquisa coordenada por Ari P. Oro (2003) mostrou que a IURD notabilizou sua inserção no campo político graças a uma "sacralização deste campo", que transformou o voto de seus fiéis num ato quase sagrado. A partir da lógica de "vigilância constante" que prima pelo enfrentamento às "forças demoníacas" que atuam no espaço público, somado a necessidade de "moralização" desse espaço público, a IURD pode ser considerada aquela denominação evangélica com maior sucesso eleitoral no Brasil.

O crescimento iurdiano, seja no campo político, seja no número de países em que se faz presente, tem relação com o pluralismo religioso existente em diferentes naçóes do mundo. Não obstante, para muitos a IURD pode significar a "entrada no mundo" de diferentes grupos sociais muitas vezes alijados de um maior pertencimento na esfera pública, especialmente no âmbito das instituições políticas. Brasileiros pertencentes às camadas mais empobrecidas da sociedade se apresentam como claro exemplo desse fenômeno. E são pessoas advindas desses segmentos sociais aquelas que se constituem como a base dos adeptos das religióes neopentecostais, ao menos na América Latina (Corten, 1996).

Anteriormente, se o discurso evangélico apresentava como um de seus sinais diacríticos mais notáveis uma espécie de "distanciamento das questôes mundanas" (Oro, 1996), com o passar do tempo e a partir da constituição de um sofisticado projeto político, sua concepção original transformou-se, de sorte que são esses grupos religiosos aqueles que se inserem com maior sucesso no campo político, ao fazer uso de uma base eleitoral sedenta por maior espaço de participação pública que encontra nos representantes políticos dessas igrejas a questionável realização de tais anseios.

No caso específico da América Latina, conforme sugeriu André Corten (1996), o pentecostalismo conseguiu modificar o fundamento teológicopolítico desta região. Tal perspectiva permite pensar se o crescimento

Debates do NER, Porto Alegre, AnO io, N. I6, P. I39-I59, JUl./Dez. 2009 
político de certas expressões religiosas evangélicas não estaria condicionado ao sentimento proporcionado por tais igrejas de aproximar determinados grupos da esfera pública. Uma vez o corpus de adeptos das denominaçóes evangélicas pertencerem às classes populares e uma vez serem pessoas desses grupos sociais aquelas que mais se percebem como não participativas da esfera política, denominaçóes como a IURD encontrariam um campo fértil para desenvolverem sua entrada na arena política? Não necessariamente, como nos mostrou o caso argentino.

Dado que o pentecostalismo "toca" (a expressão - toucher - é de Corten, 1996) as camadas mais pobres da população, também é preciso observar que atualmente existem denominaçôes evangélicas que se endereçam mais diretamente às classes média/ alta, o que pode indicar a necessidade de ampliação do mercado de fiéis disponível. Assim, a entrada em países como a Argentina teria relação, além do alegado "espírito missionário", com o empobrecimento da população proveniente das graves crises econômicas que assolaram o país a partir da segunda metade dos anos 1990, época em que a IURD desenvolveu mais satisfatoriamente sua presença no país. A rigor, o primeiro templo iurdiano em solo argentino foi aberto no final dos anos 1980, para ser mais exato (Semán, 2003).

Foi possível observar em rituais da denominação na Argentina que as pessoas buscam a instituição para encontrar subsídios simbólicos que lhes permitam ascender ao estatuto do argentino pleno, proclamado pelo discurso de nação preferencialmente como o ser católico, branco e desenvolvido moral e materialmente. De maneira completamente diferente, o mesmo não ocorreu nos terreiros afro-religiosos que pude visitar na Grande Buenos Aires, que agregam um perfil diferente de adeptos, também provenientes de setores empobrecidos da sociedade, e que ainda somam a sua identidade social marginalizada o estigma de serem negros, indígenas, homoafetivos, muitos desses transexuais ou travestis, que aparentemente não pretendem se ajustar no modelo de pessoa ditado pelo Estado, encontrando acolhimento religioso e simbólico em outro tipo de religiosidade brasileira para lá exportada, tema para outra discussão.

O problema é que, na Argentina, desde os anos que marcaram a inser-

Debates do NER, Porto Alegre, Ano io, N. I6, P. I39-I59, JUl./Dez. 2009 
ção dos evangélicos no país, suscitou-se compreender se o culto evangélico entrou em conflito com o Estado nacional por representar, no plano ideológico, uma nova forma de poder de inspiração possivelmente transnacional. Para a antropóloga Rita Segato (1991; 2003), a compreensão desta questão deve ser investigada dentre os sujeitos que interagem com uma determinada realidade religiosa, e não unicamente nos projetos originados em seus centros de origem. Ademais, atualmente, idéias e práticas religiosas viajam rápido, adentrando espaços nunca antes vistos e ambientes inimagináveis, semanticamente distintos do contexto de significado original, portanto, com uma capacidade de adaptação e de resignificação local múltiplas. Mais importante do que o pluralismo e a fragmentação do campo religioso é a pressão do sistema pelo alinhamento dos sujeitos em identidades políticas e pela formação de alianças de tipo denominacional como forma de participação dentro de um paradigma político (Segato, 2006). A política da identidade, decorrente desse processo, permite a expansão religiosa para outros territórios, inclusive para aqueles onde o déficit de participação política também seja comum entre certos grupos sociais.

No caso da presença iurdiana no país platino, sua política de inserção nos meios de comunicação (jornal, rádio e televisão) se realiza próxima do modelo aplicado no Brasil, e com o mesmo discurso marcado pela "Teologia da Prosperidade", trabalhado pela IURD de forma a reconhecer o peso das ideologias psicologizantes deveras difundidas no país. Ao invés de combater entidades sobrenaturais, como ocorre no Brasil (Ribeiro, 2005; Silva, 2007), no cenário argentino se mostrou mais eficaz apelar para condiçóes psicológicas negativas, como o estado de ânimo, etc (Oro, 2004). Portanto, se por um lado existe o plano institucional e sua "política empresarial" de conquista de fiéis e de poder, a partir do forte aparato midiático que lhe caracteriza, por outro não podemos nos esquecer do plano teológico dos sujeitos que aderem a estas religiōes. As pesquisas existentes sobre o assunto muitas vezes ignoram esse aspecto, procurando compreender a atuação dessas igrejas a partir de um discurso que soa maniqueísta, sem levar em consideração a existência de vários projetos que se articulam ao fenômeno da conversão evangélica e aos próprios projetos institucionais existentes em diferentes instâncias.

Debates do NER, Porto Alegre, Ano io, N. I6, P. I39-I59, JUl./Dez. 2009 
Ainda que a literatura especializada sobre o assunto indique que é na Argentina o país onde a IURD logrou seu maior sucesso fora do Brasil - e os números absolutos de templos e de fiéis notoriamente sustentam tal prerrogativa, é preciso relativizá-la. $\mathrm{Na}$ Argentina, a IURD é vista sem muita confiança pelas camadas médias e altas da sociedade, tampouco pelas demais denominaçóes evangélicas nacionais, reunidas sob a égide de diferentes organizaçôes, como a Federación Consejo Nacional Evangelista Pentecostal (FECEP) ou a Federación Argentina de Iglesias Evangelistas (FAIE), justamente devido as suas tentativas, enquanto instituição religiosa estrangeira, de almejar ou apoiar candidaturas a cargos públicos. Ademais, o governo argentino reluta há mais de dez anos em liberar a concessão para que a Igreja adquira um canal de televisão (TV America), rede na qual a Universal tem se contentado em alugar parte da programação diária nas madrugadas e manhãs para veicular seus programas televisivos, dimensão essencial de sua estratégia de evangelização (Fonseca, 2003).

Retomando o tema correlato da globalização, conforme a pesquisa de Aurelio Alonso (apud Segato, 2007), em 1981 criou-se nos EUA o Instituto de Religião e Democracia dentro de um contexto mundial que primava pela revitalização relativista e descentralização da espiritualidade religiosa. Esta instituição propiciou a formação de milhares de missões fundamentalistas no mundo que objetivavam "garantir" uma nova liberdade confessional. Esta iniciativa deu origem a uma série de medidas adotadas pelo Congresso estadunidense que estimulassem a pluralidade religiosa pelo mundo, como a Lei de Restauração da Liberdade Religiosa ou a Lei de Apoio à Liberdade Religiosa, sancionadas nos anos 1990. Para tanto, ao que parece, a intenção do Governo estadunidense foi a de assumir o papel de "polícia religiosa do mundo", garantindo a liberdade religiosa especialmente nos países periféricos, como os latino-americanos. Mas, por quê? Quais interesses estão em jogo para a criação, por parte do governo estadunidense, deste tipo de iniciativa?

Os governos periféricos parceiros da política exterior estadunidense podem ter facilitado a entrada de missionários em seus países e, conseqüentemente, de religióes estrangeiras. Este seria o caso da Argentina e das

Debates do NER, Porto Alegre, ano io, N. I6, P. I39-I59, JUl./Dez. 2009 
religiôes brasileiras institucionalizadas que chegaram por lá, especialmente depois da reabertura política, em meados dos anos 1980. Além disso, o projeto de privatização dos meios massivos de comunicação, analisado por José Jorge de Carvalho (1999), mostra que sua origem esteve fortemente atrelada a certos grupos religiosos estadunidenses. Como é sabido, a IURD soube se aproveitar desse projeto no Brasil que, à exemplo de países como a Argentina, adotaram o modelo originado nos EUA.

A partir destas considerações, pergunto se, por um lado, existe um projeto mundial que politicamente demanda e desenvolve certo pluralismo religioso controlável, e, se por outro, existe uma demanda social por simbolizar, a partir da religião, uma identidade particular? Isto poderia indicar parte dos motivos que facilitam a entrada de religiôes brasileiras na Argentina, uma nação que possuiu historicamente um Estado deveras centralizador e repressor para com a diferença, mas que também se associou a interesses políticos estrangeiros, dentro de uma determinada ordem mundial.

O quadro atual inspira uma análise mais aprofundada da presença da IURD na Argentina e de suas estratégias de desenvolvimento no país, que encontram um relativo êxito devido a importante adaptação de sua doutrina aos aspectos da cultura local, como sua interação com a religiosidade popular e com a cultura psicologizante, além de sua aproximação discursiva e litúrgica com o ethos católico dominante, constituindo a IURD não como mais uma oferta evangélica no país, mas antes como um modo específico de ser evangélico na Argentina (Oro, 2004). No que se refere ao panorama político institucionalizado, a IURD ainda encontra sérios obstáculos para se inserir e desenvolver esta dimensão de sua inserção na cultura argentina.

\section{DESAFIOS PARA O NOVO CENÁRIO}

O Brasil e a Argentina possuem diversas semelhanças em sua constituição social que tornam possíveis algumas das aproximaçôes aqui sugeridas. Em ambos os países, por exemplo, percebeu-se que a fragilidade das instituições da sociedade civil e do Estado conforma um contexto sócio-político peculiar,

Debates do NER, Porto Alegre, ano io, N. 16, P. I39-I59, JUl./Dez. 2009 
onde diversos grupos sociais aspiram por maior integração dentro da sociedade nacional (De Riz, 1994). Em tais contextos, certas expressóes religiosas encontram campo fértil para o seu desenvolvimento, a partir da utilização de um discurso que acalente necessidades desta natureza e correlatas.

Ao longo desta breve análise sobre o campo religioso e o político institucionalizado no Brasil e na Argentina, percebe-se de antemáo as dificuldades em se realizar uma análise comparativa, devido à tendência de simplificação dos dados de realidades distintas. Entretanto, acredito que seu valor reside em também identificar cenários culturais semelhantes, para se aprender com suas diferenças.

Especialmente na última década, ocorreu maior aproximação do Brasil junto aos seus vizinhos sul-americanos, e tanto os processos de transnacionalização religiosa, quanto cultural e intelectual receberam impulso dantes inédito, sob a égide do fenômeno da globalização e dos projetos comerciais e econômicos mundiais. Contudo, o distanciamento que temos enquanto brasileiros da imaginada identidade latino-americana é notória (Gumucio, 2008), seja em nossas instituiçóes, seja em nosso modelo maior de identidade nacional, fenômeno que ecoa uma semântica que nos distancia dos nossos países vizinhos e de suas realidades sociais, culturais e políticas, em muitos aspectos macro-sociais deveras semelhantes aos nossos. Esta discussão, absolutamente inconclusa, se insere no quadro de trabalhos e de iniciativas que levam em consideração justamente tal dimensão: a de voltar o seu olhar e o seu interesse para a nossa realidade, uma realidade tipicamente sulamericana.

\section{REFERÊNCIAS BIBLIOGRÁFICAS}

CARVALHO, José Jorge de. Um espaço público encantado: pluralidade religiosa e modernidade no Brasil. Série Antropologia, Brasília, v. 249, 1999.

CATOGGIO, María S. Gestión de la diversidad religiosa durante la última dictadura militar: el caso del Registro Nacional de Cultos. XIV Jornadas sobre Alternativas Religiosas en América Latina: Religiones/ Cultura. Buenos Aires, 2007 (Cd-Rom, v.1).

Debates do NER, Porto Alegre, Ano io, N. I6, P. I39-I59, JUl./Dez. 2009 
CORTEN, André. Pentecôtisme et politique en Amérique latine. In: Problèmes d'Amérique latine, nr. 24, 1996, p. 17-32.

DE RIZ, Liliana. Os desafios da democracia na Argentina. In: BAQUERO, Marcello (org). Cultura política e democracia: os desafios das sociedades contemporâneas. Porto Alegre: Editora da UFRGS, 1994, p. 55-75.

FONSECA, Alexandre Brasil. Igreja Universal: um império midiático. In: ORO, Ari Pedro et alii (orgs). Igreja Universal do Reino de Deus: os novos conquistadores da fé. São Paulo: Paulinas, 2003, p. 259-280.

GIUMBELLI, Emerson. O fim da religião: dilemas da liberdade religiosa no Brasil e na França. São Paulo: Attar Editorial, 2002.

GUMUCIO, Cristián Parker. Identidad latina y integración sudamericana. In: ORO, Ari P.(Org) Latinidade da América Latina: enfoques sócio-antropológicos. São Paulo: Editora Hucitec, 2008, p. 60-96.

LOBATO, Mirta. El progreso, la modernización y sus límites (1880-1916): nueva historia argentina. Buenos Aires: Sudamericana, 2000.

MACHADO, Maria das Dores Campos. Política e religião: a participação dos evangélicos nas eleiçóes. Rio de Janeiro: FGV Editora, 2006.

ORO, Ari Pedro. Avanço Pentecostal e Reação Católica. Petrópolis: Vozes, 1996.

ORO, Ari Pedro et alii (orgs). Igreja Universal do Reino de Deus: os novos conquistadores da fé. São Paulo: Paulinas, 2003.

ORO, Ari P. A presença religiosa brasileira no exterior: o caso da Igreja Universal do Reino de Deus. Estudos Avançados, 18 (52), 2004, p. 139-155.

RIBEIRO, Jaçanã. O simulacro da alteridade: uma análise discursiva do ritual de libertação e cura da Igreja Universal do Reino de Deus. 2005. Dissertação (Mestrado em Estudos da Linguagem - Análise do Discurso) - Programa de Pós-Graduação em Letras, Universidade Federal do Rio Grande do Sul, 215f, 2005.

ROMERO, Luis Alberto. História contemporânea da Argentina. Rio de Janeiro: Jorge Zahar Editor, 2006.

SEGATO, Rita Laura. Algunas Propuestas para el Estudio del Cambio Religioso: la Expansión Evangélica en la Puna Jujeña. Sociedad y Religión, v. 8, 1991. 
SEGATO, Rita Laura. Religions in transition - Changing religious adhesions in a merging world". In: SEGATO, Rita Laura; ALVARSSON, Jan-Ake. Religions in transition: mobility, merging and globalization in contemporany religious adhesions. Uppsala: Uppsala University Library, 2003, p. 8-32.

SEGATO, Rita Laura. La faccionalización de la República y el paisaje religioso como índice de una nueva territorialidad. In: ALONSO, Aurelio (Org). La América Latina y el Caribe: Territorios Religiosos y Desafios para el Diálogo. Buenos Aires: CLACSO, 2006, v. 1, p. 48-82.

SEGATO, Rita Laura. La nación y sus otros: raza, etnicidad y diversidad religiosa en tiempos de Políticas de la Identidad. Buenos Aires: Prometeo Libros, 2007.

SEMÁN, Pablo. A Igreja Universal na Argentina. In: ORO, Ari Pedro et alii (orgs). Igreja Universal do Reino de Deus: os novos conquistadores da fé. São Paulo: Paulinas, 2003, p. 69-78.

SILVA, Vagner Gonçalves da (org.). Intolerância religiosa. São Paulo: EDUSP, 2007.

SOLER, Ricaurte. El positivismo argentino. Buenos Aires: Editorial Paidos, 1968.

WEBER, Max. Economia e sociedade. Volume 1. Brasília: Editora da UnB, 2004. 
